\title{
THE FIRST ARAB NOVEL IN ENGLISH: THE BOOK OF KHALID
}

\author{
Suheil B. Bushrui, University of Maryland ${ }^{1}$ \\ Email: sbushrui@umd.edu
}

\begin{abstract}
The Book of Khalid, written by the Lebanese writer Ameen Rihani (18761949), illustrates the author's concern for reconciling the culture and values of East and West; the novel is central to understanding his thoughts on the great issues which shaped twentieth-century history, as well as a work of lasting wisdom, over a hundred years after its first appearance. Like Rihani himself, who reconciled two disparate cultures more than almost any other writer of the time, Khalid, having experienced America (and considered its strengths and weaknesses) during a stay of several years, returns to develop a philosophy that engages the Arab public directly.

Keywords: English-Arab Novel, East-West Cultural Relations, 20 ${ }^{\text {th }}$ Century, Arab philosophy, Spiritual Quest, Unity of Religions.
\end{abstract}

Title in Spanish: La primera novela árabe en inglés: The Book of Khalid.

Resumen: The Book of Khalid, escrito por el autor libanés Ammen Rihani (1876-1949), ilustra el interés del autor por reconciliar la cultura y los valores de oriente y occidente; la novela es fundamental para entender sus ideas sobre los grandes temas que configuraron la historia del siglo XX, además de ser una obra de sabiduría perdurable, un siglo después de su primera aparición. Al igual que Rihani mismo, quien reconciliaba dos culturas distantes más que casi ningún otro escritor de la época, Khalid, habiendo tenido la experiencia de América (y considerado sus ventajas y debilidades) durante una estadía de varios años, vuelve para desarrollar una filosofía que atrae directamente al público árabe.

Palabras clave: Novela anglo-árabe, relaciones culturales oriente-occidente, siglo XX, filosofía árabe, búsqueda espiritual, unidad de religiones.

One hundred and two years ago, in 1911, the young Lebanese writer Ameen Rihani (1876-1940) published what is regarded as the first Arab-American novel, The Book of Khalid. This immensely spiritual work, drawing copiously from his own experience as an immigrant to the United States where he had settled as a boy, is central to understanding his thoughts on the great issues which shaped twentieth-century history. Like the hero of The Book of Khalid, Rihani found himself sickened and disillusioned by the materialism of the country he had made his home, and dismayed by what he regarded as the dangerous effects of materialistic values on humanity's spiritual and social development.

Although Rihani in his versatility has commented on a variety of subjects, and at times explored recondite and esoteric material, the two main themes that captured his imagination

\footnotetext{
Date of reception: 7 February 2013
}

Date of Acceptance: 8 July 2013 
were religion and liberty. These subjects suffuse his Arabic and English books, articles, and poetry. Rihani's master was the blind poet, Abu-al-Ala al-Marri, perhaps the greatest Arab poet of all time, who himself was obsessed by the causes of liberty and religious truth. In this paper I concentrate on one of these two themes, namely religion, while not neglecting the question of freedom of conscience. Today, perhaps no two themes are more appropriate for discussion than these. Here we can recall the words of the great British cosmopolitan and distinguished historian, Lord Acton (1980: 1):

The best things that are loved and sought by men are religion and liberty, not pleasure or prosperity, not knowledge or power. Yet the path of both are stained with infinite blood.

The early twentieth century was a period of history characterized in W.H. Auden's immortal poem as "The Age of Anxiety." It was a time of revolutions and world wars, of economic volatility, and of sudden encounters between peoples and cultures that until then had remained largely isolated from each other. Across vast regions of the globe, the collapse of monarchies and caliphates, of empires and colonial dependencies, swept away in the blink of an eye the very structure and foundation of ordered life. This in turn produced feelings of estrangement, despair, anxiety, and restlessness-a spiritual crisis that permeated virtually every corner of the planet.

Rihani's response to "The Age of Anxiety" in the pages of The Book of Khalid reflects the specific conflicts and challenges facing the immigrant Lebanese community in the United States. Yet it is a measure of Rihani's greatness that he also captures the anxieties of mankind at large. Because he engages both the specific and the universal, Rihani's work deserves close and careful analysis.

Despite a tendency among many readers and critics to see his life and work in terms which lend themselves to appropriation, if not outright exploitation for political ends, it is possible, and indeed essential, to place them in a far wider context-one which does not limit them to narrow sectarian interests which were inimical to Rihani's own view of the world. Indeed, Lebanon's history taught Rihani the dangers of factionalism and sectarianism, and he had nothing but contempt for those who would exploit religious sentiments for political purposes. He wrote:

O God, Bestow upon me a drop of the ocean of Thy knowledge so that I may be shielded from those who exploit for gain the life to come. ${ }^{2}$

While not denying the significance of his political writings, it is important to consider the ideals which inspired them, especially that of peace among the religions. In 1922, Rihani travelled throughout Arabia, meeting and becoming acquainted with its rulers; he was the only traveler of any nationality at that time to have traversed that whole territory in one trip, acquiring an invaluable, firsthand understanding of the character, vision, and beliefs of each Arab leader. Particularly in the present climate, his abhorrence of chauvinism based on religious intolerance, which he regarded as one of the major drawbacks to the development and prosperity of the Arab world, deserves comment (Rihani, 1927: 15):

From an original manuscript by Ameen Rihani, in possession of Suheil Bushrui and translated by him. 
One of the great obstacles encountered by Easterners in general and Arabs in particular in the face of advancement and progress is a diabolical obstacle that can serve only those who are ignorant and who are victims of blind obedience, an obedience which is linked to personal gain or interest and which demolishes liberty and independence. This obstacle has been created by the leaders of religion...An obstacle that attracts to its domain everyone who fears the light-the light of knowledge, the light of liberty, the light of civil advancement...An obstacle that is divisive and separates people from people and incites one group against another, thus loosening the elements that bind together a nation and destroying the national foundation.

It is indeed a formidable obstacle and we shall never achieve a sublime life or a collective national life unless we overcome this obstacle...It is not religion per se that I am referring to here, for religion is simple, easy, and offers a wide embrace with many paths for all the peoples of the world. The real obstacle, of course, is one that is surrounded by barbed wire. That obstacle is the exclusive confessional community; it is the exclusive body of adherents. It is in fact the tribe. It is the concept of a small human community that excludes itself from the larger human community, and hence cannot see goodness in anyone except its own number and will never desire benefit for anyone but its own kind.

Rihani divided The Book of Khalid into three sections, and these correspond to the pillars of his own philosophy, namely: Man, Nature, and God. It is under these headings that I propose to explore Rihani's thought.

First, however, we should briefly outline the plot of the novel and consider something of the circumstances in which Rihani came to write it, as these are inseparable from his message which transcends the boundaries of a specific time and social group to extend to all of humanity.

Ameen Rihani, born November 24, 1876, arrived in New York City at the age of eleven in the company of his uncle. His father Ferris Rihani, a Maronite Christian from Freike, Lebanon, who worked as a raw silk manufacturer, joined them a year later. The elder Rihani and his brother established a business in Lower Manhattan, and like many immigrant children, Ameen's studies in English were interrupted by the need to share his new skills with the family business. In his spare time, the bustling New York literary community exposed the young Rihani to American and European writers. Under these influences, and while serving as his father and uncle's chief clerk, interpreter, and bookkeeper, he developed an affinity for Emerson, Tolstoy, Shakespeare, and Byron, to name only a few.

By 1895, Rihani was old enough -and bold enough- to strike out on his own, albeit briefly. A blossoming stage fever led him to share his natural speaking abilities with a touring repertory company where he worked with Henry Jewet, who later operated a theatre in Boston. Unfortunately, the troupe was stranded in Kansas City, Missouri, after only a few months, and the prodigal son returned home. He chose not to rejoin the family business, however, insisting on a formal education to prepare himself for a professional career. Law was the direction chosen, and after attending night school for a year, Rihani passed the Regent's Exam and entered New York Law School in 1897.

But the roadblocks to his personal aspirations continued. A lung infection interrupted his studies and his father sent him home to Lebanon to recuperate. As he healed, Rihani traded lessons in English at a clerical school for instruction in his native Arabic. A growing 
interest in Arabic and Eastern poetry which began in 1897 led him to Abu-al-Ala al-Marri, whom he declared to be a precursor of Omar Khayyam.

After Rihani's return to New York in 1899, he became active in New York literary and artistic salons including the Pleiades Club and the Poetry Society of America. Rihani began translating Abu-al-Ala al-Marri into English, while at the same time contributing regularly to Al-Huda, a daily Arabic newspaper published in New York. Rihani produced original works in English as well, and according to Lebanese historian Sami Kassir, Rihani was the first Arab to do so without turning his back on his native language. His first books in Arabic were published in 1902 and 1903, and his first English translation of Abu-al-Ala al-Marri appeared in 1903. Rihani's works on religion, politics, philosophy, and social customs set the tone for his literary career.

Lebanon drew him home and Rihani returned to his native mountains in 1905 . He carried with him a love of America, and Rihani introduced free verse from the likes of Walt Whitman into Arab poetry-a lasting influence which continued in the Arab world after Rihani's death in 1940 and well into the second half of the twentieth century. A six-year period of solitude allowed Rihani to produce many Arabic works as well, encompassing two volumes of essays, a book of allegories, and a few short stories and plays.

Rihani shared his talents with the broader community, teaching at institutions such as the Syrian Protestant College (later The American University of Beirut) and others, and in cities across the region including Jerusalem, Aleppo, Damascus, Cairo, and farther afield. Yet he did not limit his work to academia. He toiled with others to free his beloved Lebanon from Turkish rule. His 1910 Ar-Rihaniyyaat led the Egyptian media to title him "The Philosopher of Freike," and solidified his credibility as a visionary and a progressive thinker.

The Book of Khalid, which was published in 1911 after Rihani's return to New York, was written during his earlier noted period of self-imposed isolation. This first-ever English novel written by a Lebanese-Arab was graced with illustrations by Khalil Gibran, and led to Rihani being crowned with a laurel wreath by the president of the New York Pleiades Club during a reception launching the book. Scholars have praised this novel as the foundation of a new literary trend toward wisdom and prophecy which seeks to reconcile matter and soul, reason and faith, and the Orient and Occident. It is an attempt to expound the unity of religions and to demonstrate the harmony of the universe.

The novel tells the story of two boys, Khalid and Shakib, from Baalbek in Lebanon (at the time a province of the Ottoman Empire). They migrate to the United States, coming by ship through Ellis Island with all the legendary difficulties of the immigrant. The young men take up residence in the Little Syria community of Lower Manhattan near Battery Park and engage in a typical Arab practice of the day to earn a living in America: they sell trinkets and counterfeit religious items from the Holy Land throughout the city. Eventually, Khalid turns away from the retail business which thoroughly occupies Shakid the poet. Khalid destroys his entire inventory at one point, and immerses himself in Western literature and in the unconventional New York intellectual societies.

But the attraction of these "bohemian" pursuits soon wanes. Khalid is offered a position as a functionary and warden for the Arab community in the city government, and he turns his energies to party politics. His insistence on moral integrity creates animosity with his superiors, however, and Khalid finds himself behind bars for ten days charged with misuse 
of public funds. After Shakid helps to secure his release, the two decide to return to Lebanon, which, unfortunately for Khalid, necessitates selling merchandise on the street again to earn money to pay for the trip.

Back in Lebanon, Khalid's independent thinking continues to create problems for the young man. He angers Maronite clerics in his native city by refusing to attend church services and by propagating heretical ideas. His request to marry his young cousin Najma is denied by church leaders and Khalid is excommunicated. After Najma is pressured into marrying another man, Khalid retreats to the mountains to live in solitude.

His self-imposed exile allows Khalid the opportunity to mediate on nature and to solidify a growing realization that his "heretical" ideas on the difficulties faced in his homeland, both political and cultural, mesh with much of what he encountered in America. Khalid begins travelling throughout the Arab world as a self-described "voice" for his people on the importance of religious unity and scientific progress, and on liberation from the Ottoman Empire. Along the way, Khalid meets an American Baha'i woman, a Mrs. Gotfry, and they share deep discussions on the questions of love and religion.

When Khalid speaks in the Great Mosque in Damascus about religious tradition and his views on the West, a riot ensues and Ottoman officials order his arrest. He escapes with Mrs. Gotfry and they join Shakib in Baalbek. Khalid reunites with the abandoned and ill Najma, now with a young son, and the five of them flee to the Egyptian desert.

After several happy months in the desert, Mrs. Gotfry and Shakib depart, leaving Khalid and Najma behind. Soon after, Najma's son Najid dies suddenly, Najma relapses into her illness and, in her grief, follows him in death. This time, Khalid does not turn to Shakib for help; he disappears.

The central theme of The Book of Khalid is an attempt to reconcile the culture and values of East and West. This was a universal concern in Rihani's work, and indeed of his whole approach to life. Khalid constantly reflects on the merits and future destiny of America, which he connects with the Arabs in their own struggle with the Ottoman Empire and with religious intolerance and conflict. Like Rihani himself, who reconciled two disparate cultures more than almost any other writer of the time, Khalid, having experienced America (and considered its strengths and weaknesses) during a stay of several years, returns to develop a philosophy that engages the Arab public directly. Khalid is continually frustrated by America's materialism and inconsistent pursuit of its stated ideals, but nevertheless believes that America represents a powerful force in the world's future evolution. He is certain that the Arab world could learn much from America's political ideals, relative respect for religion, and embrace of science and progress. Although these expressions result in his own persecution, Khalid emerges as a prophet for his time with a combined political, cultural, and spiritual message.

Throughout the novel, there occurs a strong vein of satire, irony, and scepticism with regard to human folly which is only too evident both in Lebanon and America, but this never degenerates into cynicism. Like Nietzsche's Zarathustra, Khalid is driven to cry out against the folly and gullibility of modern man, but not to reject it as beyond redemption. Like Chaucer's Pardoner, Khalid is sufficiently clear-sighted to feel disgust for his own deceptive practices in convincing a credulous public to buy spurious relics and "sacred" wares. But at the same time, he displays a certain pragmatism, again reminiscent of 
Nietzsche, when he returns to peddling for the purpose of financing his return home to enlighten his Lebanese compatriots.

Rihani depicts the challenges which Khalid faces squarely and without sentimentality. He does not play down the tendency towards religious bigotry and exclusiveness which mars the spiritual climate in which Khalid moves, and in so doing he shows Khalid as flawed in the eyes of his community but as a heroic figure in his unflinching acceptance of his duties. To accomplish his goals, Khalid needs to draw spiritual nourishment from nature, retreating not in a self-absorbed withdrawal from a sullied world, but for the express purpose of strengthening himself for his labours. He quotes Emerson, to be sure: "A dilettantism in Nature is barren and unworthy." For Khalid, the pines of his native Lebanon serve as a symbol of the difference between his native and adopted lands. Visiting the great mosques of Cairo, he recalls those trees:

Yes, the pine forests are the great mosques of nature...Here in this grand Mosque of Nature I read my own Koran. I, Khalid, a Bedouin in the desert of life, a vagabond on the highway of thought, I come to this glorious Mosque, the only place of worship open to me, to heal my broken soul in the perfumed atmosphere of its celestial vistas. The mihrabs here are not in this direction nor in that. But whereso one turns there are riches in which the living spirit of Allah is ever present. Here, then, I prostrate me and read a few Chapters of MY Holy Book. After which I resign myself to my eternal Mother and the soft western breezes lull me asleep. Yea, and even like my poor brother Moslem sleeping on his hair-mat in a dark corner of his airy Mosque, I dream my dream of contentment and resignation and love. ${ }^{3}$

The whole of this book begins with an address to Nature, in which Rihani, in the person of Khalid, invokes her as his "Mother eternal, divine, satanic, all-encompassing, all nourishing, all-absorbing." Once again, there is no trace of mawkishness in his conception of nature, which is both bountiful and ruthless, a force of both creation and destruction, offering a love "both divine and diabolic."4 Drawing on Emerson, Thoreau, and Wordsworth, Rihani acknowledges the sublimity and healing power of nature, but also its darker aspects. Yet without nature, man himself cannot exist. The first book, "In the Exchange," commences with an invocation to Man:

No matter how good thou art, O my Brother, or how bad thou art, no matter how high or how low in the scale of being thou art, I still would believe in thee, and have faith in thee, and love thee...Look up, therefore, and behold this World-Temple, which, to us, shall be a resting-place, and not a goal. On the border-line of the Orient and Occident it is built, on the mountain-heights overlooking both. No false gods are worshipped in it, no philosophic, theologic, or anthropomorphic gods. ${ }^{5}$

\footnotetext{
3 Ameen Rihani, "Chapter VIII, "The Kaaba of Solitude"” in The Book of Khalid, "Book the Second: In the Temple,” (Beirut: The Rihani House, 1973), p.180.

4 Ameen Rihani, "To Nature" in The Book of Khalid, "Book the Second: In the Temple," (Beirut: The Rihani House, 1973), p. 97.

5 Ameen Rihani, "Book the First: In the Exchange," in The Book of Khalid, (Beirut: The Rihani House, 1973), p. 3 .
} 
These lines convey a truth which lies at the heart of Rihani's spirituality. Regarding all men as brothers in the tradition of the all-embracing generosity of Schiller's "Ode to Joy," Rihani accepts them without partiality or reservation as fellow-worshippers in a universal temple from which none is excluded. In this temple, dogma and bigotry have no place. The refreshment which springs forth from the fountain in the temple of the presiding God of Humour is sorely needed by the young Khalid as we meet him in the following pages, struggling to come to terms with the perplexities and disappointments that await him and his friend in their adopted country, and with the disillusionment that Khalid encounters after his return to Lebanon.

Khalid's story is a reflection of the experiences which shaped Rihani's own view of spirituality, including his distrust of organized religion and the recognition of its power to thwart the very purposes that it claimed to pursue. Above all, Rihani sought to expose the kind of intolerance that threatened to undermine peace among the religions of the world. Addressing his Arabic readers, he warned them of the danger of parochialism and chauvinism, and of the imperative need to create open, pluralistic societies where religious, ethnic, and racial prejudices had no place. In one of his Arabic essays, Rihani wrote:

Remove those banners above your head-speaking of sects and factions-and erase from the tablet of your heart what your predecessors have inscribed therein of prejudice or envy. Purify, my brother, the tablet within yourself and erase from it all traces of defilement. Be thou none other than thyself and inscribe upon this tablet the beautiful, sweet words: Liberty, Truth, Love, Beauty; and be a true human being. ${ }^{6}$

Of paramount importance in this context is the principle that guided Rihani throughout his life, namely promoting a strong and mutually beneficial relationship between East and West. On a personal level, Rihani lived this East-West dialogue through his 1916 marriage to the American artist Bertha Case. Professionally, Rihani advanced the cause through his activities with a remarkable group of Arab immigrants in the United States, some Syrian and the majority Lebanese, who came to exert a powerful influence both on the Arab cultural renaissance as well as on interfaith and intercultural relations between the West and the Arab world.

This group of artists, essayists, poets, and philosophers-which included Rihani, Kahlil Gibran, and Mikhail Naimy-acted as cultural ambassadors between East and West at a significant historical moment when modernity and globalization were being thrust on the Arab world as a result of its newly found oil wealth, and when America was emerging as a global centre of economic activity and material advancement. Rihani and the others in his circle served, through their incisive pens and poetic visions, as oracles who foresaw with piercing clarity the nature of the spiritual challenges confronting both America and the Arab world.

In our present age of globalization and religious sectarianism, with its attendant perils of terrorism and conflict in the name of distorted religion, Rihani's message is more timely than ever. Over and over again he resists the narrowing-down of the concept of God in the pursuit of a restrictive and legalistic view of religion, and its misappropriation for political

\footnotetext{
${ }^{6}$ Ameen Rihani, original manuscript translated from the Arabic by Suheil Bushrui.
} 
ends. His third section of The Book of Khalid opens with an address to God Himself (Rihani, 1973: 237):

In the religious systems of mankind, I sought thee, $\mathrm{O}$ God, in vain; in their machinemade dogmas and theologies, I sought thee in vain; in their churches and temples and mosques, I sought thee long, and long in vain; but in the Sacred Books of the world, what have I found? A letter of thy name, O God, I have deciphered in the Vedas, another in the Zend-Avesta, another in the Bible, another in the Koran. Ay, even in the Book of the Royal Society and in the Records of the Society for Psychical Research, have I found the diacritical signs which the infant races of this Planet Earth have not yet learned to apply to the consonants of thy name. The lisping infant races of this Earth, when will they learn to pronounce thy name entire? Who shall supply the Vowels which shall unite the Gutturals of the Sacred Books? Who shall point out the dashes which compound the opposite loadstars in the various regions of thy Heaven? On the veil of the eternal mystery are palimpsests of which every race has deciphered a consonant. And through the diacritical marks which seers and paleologists of the future shall furnish, the various dissonances in thy name shall be reduced, for the sake of the infant races of the Earth, to perfect harmony.

Here Khalid opposes a spontaneous response to immanent and transcendental divinity to the systems created by mankind in an attempt to contain and delimit it, which by the very nature of humanity are finite and can have no claim to be otherwise. He implicitly warns against the dangers of confining God within their boundaries, and while it cannot be said that he explicitly identifies God with nature, there is a sense that both are all-encompassing and all-embracing, and as such beyond any human capacity to define or compress them within man-made frameworks of doctrine or prescription.

Central to this process, of course, was Rihani's recognition that religious leaders did not have a monopoly on revelation or the exclusive right to transmit it to mankind. In 1924, he addressed the following words to his long-time and respected Muslim friend, Sheikh Abdul Qadir al-Maghribi:

The difference between me and you, my dear friend, is that you believe in a comprehensive and complete revelation, a revelation that is completely free of human error, a revelation that is valid for every generation and for all times. While I believe in a variety of revelations in which not only the great prophets of God have a share, but also the great poets. This is a revelation that is progressive and diverse both in quantity and quality. A part of it will be valid for every generation, everywhere and at all times, and a part of it will be of no value except for a specific people, at a specific time, and in a specific place. Once it fulfils its mission, it becomes like the electric or steam engine, which looses power received from the motor that moves it. In the Qu'ran, it says: "For every time there is a book." For me, all the sacred books, and I say all, are one in my sight whether they are large in scope or small. ${ }^{7}$

A poetic thinker himself, Rihani was in a unique position to understand the role of the intuitive and poetic in the process of revealing universal truths to humanity, recognizing, for

\footnotetext{
7 Ameen Rihani, Letter to Sheikh Abdul Qadir al-Maghribi, circa 1924, original manuscript translated from the Arabic by Suheil Bushrui.
} 
example, the significance of a poet such as Shelley, who was arraigned for his defence of atheism, as a genuinely spiritual and revelatory thinker capable of communicating insights to humanity which would ultimately contribute to their understanding of the mysterious communion between man and the divine. Nor did Rihani have any illusions about the ability of religion to deviate from its first principle sin in the interests of worldly advantage:

The Christians lived for three hundred years as a minority religion in amity with each other, united in both prosperity and adversity, upholding peace, refusing to allow the sword to be a judge among men, and while at all times they were persecuted by the powerful on earth. But during the reign of Constantine the Great, Christians bartered their gospel for a decree that provided them protection against persecution and made their faith the official state religion. Henceforth, Christians were enlisted to wage war under the banner of the state, and so Christianity forsook the teachings of its founder to "love your enemies, [do good to them that hurt you], bless them that curse you [and pray for them which despitefully use you]."

Thus Christianity marched in the army of the mightiest colonizing power known to ancient history. The followers of Him who had said: "My kingdom is not of this world," ended up by making Him a worldly Emperor, and on His head that had known none but thorns, they placed a worldly crown.

Ultimately they found themselves burdened with an enormous debt towards their faith, that faith which remained as a witness before heaven and earth asking them to answer for all those deeds they had done. For regardless of the civilization they had built, a civilization that astonished the mind, eye and ear, nothing would protect them against the price they had to pay for betraying their Christ. ${ }^{8}$

The Book of Khalid begins on a note which introduces an element of scepticism from the outset in its claim to be a manuscript discovered in the Khedivial Library of Cairo. The reader may make connections, consciously or unconsciously, with instances of "manuscripts" such as Thomas Chatterton's, or the poems of Ossian, which were passed off as something which they proved not to be, but not before leading or misleading a wide public into belief of their authenticity. Rihani makes-at any rate explicitly-no such assertions. Yet he is united with these in the fact that their authenticity, literal or otherwise, is not the main issue; the profound poetic truths which they convey in their expression of a need for acknowledgement of issues which cannot be raised in any other way-whether national or individual poetic voice, or one capable of speaking peace between nations and religions-are the foundation on which they rest. In his hatred of hypocrisy and cant, and in his rejection of the power of false religion to corrupt and pervert human progress towards universal brotherhood and lasting understanding, Ameen Rihani created, in The Book of Khalid, a profound and enduring testimony to his deeply-held convictions, as well as a work of lasting wisdom which, a century after its first appearance, becomes ever more timely in proportion to the increasingly pressing need for such understanding at the deepest spiritual level between East and West.

\footnotetext{
$8 \quad$ Extract from a conversation in Arabic between Mikhail Naimy and Suheil Bushrui recorded in 1976 and translated by Suheil Bushrui.
} 


\section{REFERENCES}

Acton, H. 1980. "Lord Acton: A Great Cosmopolitan," in Essays by Divers Hands, New Series, vol. XLI. Ed. Brian Fothergill. London: The Royal Society of Literature.

NAIMY, M., 1976. Original recording, translated from the Arabic by Suheil Bushrui.

RiHANI, A. (undated) translated from the Arabic by Suheil Bushrui.

---. 1924 (circa). Letter to Sheikh Abdul Qadir al-Maghribi, circa 1924, translated from the Arabic by Suheil Bushrui.

---.1927. The Reform of the Nation, (Haifa, Jerusalem, Nablus and Nazareth, Palestine: YMCA), translated from the Arabic by Suheil Bushrui.

---.1973. The Book of Khalid, (Beirut: The Rihani House). 